\title{
Effect of Drying Characteristics of Garlic-A Review
}

\author{
Singh Papu ${ }^{1^{*}}$, Amar Singh ${ }^{1}$, Singh Jaivir ${ }^{2}$, Singh Sweta ${ }^{2}$, Arya AM ${ }^{2}$ and Singh BR $^{2}$
}

${ }^{1}$ Division of Agricultural Engineering, Indian Agricultural Research Institute, New Delhi, India

${ }^{2}$ Department of Agricultural Engineering and Food Technology, College of Agriculture, SVP University of Agriculture and Technology, Meerut- 250110, UP, India

${ }^{*}$ Corresponding author: Singh Papu, Division of Agricultural Engineering, Indian Agricultural Research Institute, New Delhi-110012, India, Tel: 01234-273028, 09759678365; E-mail: papusinghujjwal@gmail.com , papuujjwal@yahoo.in

Rec Date: Mar 18, 2014, Acc Date: Apr 26, 2014, Pub Date: May 08, 2014

Copyright: () 2014 Papu S, et al. This is an open-access article distributed under the terms of the Creative Commons Attribution License, which permits unrestricted use, distribution, and reproduction in any medium, provided the original author and source are credited.

\begin{abstract}
Natural sun drying is one of the most common ways to preserve agricultural products. The main purpose in drying farm produce is to reduce its water activity from the harvest level to the safe storage level in order to extend its shelf life. Once the produce has been dried, its rate of deterioration due to respiration, insects, and microbial activity and biochemical reactions should diminish leading to maintenance of quality of the stored product. It is improve bargaining position of the farmer to maintain relatively constant price of his product. Drying reduces post-harvest losses and transportation costs since most of the water are taken out from the product during the drying process. In India, sun drying is the most commonly used method to dry the agricultural material like grains, fruits and vegetables. In sun drying, the garlic is spread in a thin layer on the ground and exposed directly to solar radiation, ambient temperature, wind velocity, relative humidity, initial moisture content, absorptive, exposure time and mass of product per unit exposed area. Direct sun drying has been a popular method of crop drying in the farms and villages. Sun drying allows for the production of a product rich in colour and translucent in appearance, but it has some disadvantages (e.g. it is a time-consuming process, weather depended, labour demanded and it is greatly exposed to possible environmental contamination. Solar driers using natural convection or forced circulation have been investigated to overcome these problems. For commercial applications, the ability of the dryer to process continuously throughout the day is very important to dry the garlic to its safe storage level and to maintain the its quality. Garlic (Allium sativum L.) is a nutritional herbaceous plant known for its medicinal as well as culinary benefits, which originated from the mountains of Central Asian regions Globally, China is by far the largest producer of garlic, producing over $75 \%$ of world tonnage followed by India, Korea, and the USA (FAOSTAT, 2005). Food drying is one of the oldest methods of preserving food for later use.
\end{abstract}

Keywords: Garlic; Sun drying; Greenhouse solar drying; Slices and drying techniques

\section{Introduction}

Garlic (Allium satium L.) is a bulbous perennial vegetable spice. The bulb is composed of pungent bolblets, commonly known as cloves. Garlic is a semi-perishable product. Due to lack of suitable storage and transportation facilities, about $30 \%$ of fresh crop is wasted by respiration and microbial spoilage [1]. At times of shortages, India imports garlic of Chinese origin from Taiwan or via Nepal [2]. Fresh garlic, dehydrated garlic flakes, dehydrated garlic powder and garlic oil is exported from India. India was once a leader in this field but is losing out to China in the overseas market. China has an edge over India in terms of both quality and quantity. The area and production of garlic in India and the world, top $1^{\circ}$ garlic producers in 2013 is given in table.

Like other biological crops [4], garlic (Allium sativum L.) is subject to waste due to respiration and microbial spoilage during storage. Garlic has been cultivated for centuries all over the world on account of its culinary and medicinally properties. It is mainly used as a condiment in various food preparations such as flavouring mayonnaise and tomato ketchup-sauce, salad dressing, meat sausages, stews spaghetti, chutney, and pickles etc. Drying is an alternative to minimize the losses to a considerable extent. Garlic cloves with approximately $1.85 \mathrm{~g}$ water/g dry matter are dried to a safe moisture content of $0.06 \mathrm{~g}$ water/g dry matter. Currently hot air drying method is used for drying the garlic [2,5,6]. Moisture removal from solids is an integral part of food processing. Many food products are dried at least once at some point in their preparation. Drying fruit and vegetable products is an important means of enhancing resistance to degradation due to a decrease in water activity (aw). Easier processing, lower transport costs as well as quality enhancements can also be achieved $[7,8]$. Drying is an important operation in the food and pharmaceutical industries and is accomplished by air, vacuum, spray and freeze-drying techniques [9]. Heated air drying is the most commonly employed commercial technique for drying biological products, and although large quantities of drying information are available in the literature, the process still remains largely an art [7]. Fruits and vegetables are highly seasonal and available in plenty amounts in particular times of the year. In the peak season, the selling prices are usually at the minimum and this may lead to lower profits or even losses for the grower. Preservation of these fruits and vegetables can prevent the huge wastage and make them available in the offseason at remunerative prices [10]. Sun drying is still the most common method used to preserve agricultural products in most tropical and subtropical countries (Table 1). Garlic is an important agricultural product that is a strong source of phenolic materials, phosphorus, potassium, sulphur, zinc, selenium and vitamins $\mathrm{A}$ and $\mathrm{C}$, and lower levels of the elements calcium, sodium, magnesium, manganese, iron and B complex vitamins [11]. It has antiseptic properties and used in a number of medicinal preparations. Various garlic powder pills and garlic oil pills are now commonly available 
Page 2 of 6

[12]. Afzal [13] reported that air velocity during convective grain drying in thin layers has little influence (would normally increase although may not substantial) on the moisture removal rate. The convective heat transfer coefficients for some crops (green chillies, green peas, white gram, onion flakes, potato slices and cauliflower) under open sun drying were reported by [14]. India produced nearly 4.39 million tonnes of garlic throughout 2006 and 2007 and exported $12,210.79$ tonnes of garlic in 2006-07. The export has been $2-3 \%$ of the total production. The export has been 42000 tonnes of dehydrated garlic products $[3,15]$.

\begin{tabular}{|l|l|}
\hline Country & Production (tonnes) \\
\hline China & $13,664,069$ \\
\hline India & 833,970 \\
\hline South Korea & 271,560 \\
\hline Egypt & 244,626 \\
\hline Russia & 213,480 \\
\hline Myanmar & 185,900 \\
\hline Ethiopia & 180,300 \\
\hline United States & 169,510 \\
\hline Bangladesh & 164,392 \\
\hline Ukraine & 157,400 \\
\hline World & $17,674,893$ \\
\hline
\end{tabular}

Table 1: Top 10 garlic producers in 2013. (Source: UN Food \& Agriculture Organisation (FAO) [3])

\section{Drying}

Food drying is one of the oldest methods of preserving food for later use. Food drying is a very simple, ancient skill. It is one of the most accessible and hence the most widespread processing technology. Sun drying of fruits and vegetables is still practiced largely unchanged from ancient times. Traditional sun drying takes place by storing the product under direct sunlight. Sun drying is only possible in areas where, in an average year, the weather allows foods to be dried immediately after harvest. The main advantages of sun drying are low capital and operating costs and the fact that little expertise is required. The main disadvantages of this method are as follows: contamination, theft or damage by birds, rats or insects; slow or intermittent drying and no protection from rain or dew that wets the product, encourages mould growth and may result in a relatively high final moisture content; low and variable quality of products due to over-or underdrying; large areas of land needed for the shallow layers of food; laborious since the crop must be turned, moved if it rains; direct exposure to sunlight reduces the quality (colour and vitamin content) of some fruits and vegetables. Moreover, since sun drying depends on uncontrolled factors, production of uniform and standard products is not expected. The quality of sun dried foods can be improved by reducing the size of pieces to achieve faster drying and by drying on raised platforms, covered with cloth or netting to protect against insects and animals. In open sun drying, there is a considerable loss due to various reasons such as rodents, birds, insects and microorganisms. The unexpected rain or storm further worsens the situation. Further, over drying, insufficient drying, contamination by foreign material like dust dirt, insects, and micro-organism as well discoloring by UV radiation are characteristic for open sun drying. In general, open sun drying does not fulfill the quality standards and therefore it cannot be sold in the international market [16]. Drying is a critical step in the processing of dehydrated products because of the high energy requirement of the process (due to low thermal efficiency of dryers. Increased consumer awareness of food quality as well as the desire to produce a high quality has emphasized the necessity of optimization. Dryer design, simulation and optimization are complex processes still based on experimental data [17]. The use of artificial drying to preserve agricultural commodities is expanding, creating a need for more rapid drying techniques and methods that reduce the large amount of energy required in drying processes. New and innovative techniques that increase drying rates and enhance dried garlic quality are receiving considerable attention [18]. Drying is dependent on the two fundamental process-Heats and Mass transfer, heat has to be transferred into the fresh products which are then followed by the removal of moisture from the products [19].

Drying also reduces shrinkage during subsequent handling, reduces the occurrence of sprouting, and allows the crop to ripen before fresh consumption or long-term storage [20]. Due to the current trends towards higher cost of fossil fuels and uncertainty regarding future cost and availability, use of solar energy in food processing will probably increase and become more economically feasible in the near future. Solar dryers have some advantages over sun drying when correctly designed. They give faster drying rates by heating the air to $10-30^{\circ} \mathrm{C}$ above ambient, which causes the air to move faster through the dryer, reduces its humidity and deters insects. The faster drying reduces the risk of spoilage, improves quality of the product and gives a higher throughput, so reducing the drying area that is needed. However care is needed when drying fruits to prevent too rapid drying, which will prevent complete drying and would result in case hardening and subsequent mould growth. Solar dryers also protect foods form dust, insects, birds and animals. They can be constructed from locally available materials at a relatively low capital cost and there are no fuel costs. Thus, they can be useful in areas where fuel or electricity are expensive, land for sun drying is in short supply or 
expensive, sunshine is plentiful but the air humidity is high. Moreover they may be useful as a means of heating air for artificial dryers to reduce fuel costs 18 . Drying is probably the oldest and the most important method of food preservation practiced by humans. This process improves the food stability, since it reduces considerably the water and microbiological activity of the material and minimizes physical and chemical changes during its storage.

\section{Effect of drying characteristic on quality of garlic}

The purpose of the present study was to test and to evaluate the effect of different levels of infrared radiation intensity and air velocity on drying characteristics and quality changes of thin layer garlic slices under convection and combined heating modes. The major quality problems faced during garlic drying loss of flavour, discoloration and poor rehydration characteristics of the dried garlics. Garlic flavour and colour are generally perceived as important quality attributes. In drying, diffusivity is used to indicate the flow of moisture from the material. In the filling rate period of drying moisture removed is controlled mainly by molecular diffusion. Diffusivity is influenced by shrinkage, case hardening during drying, moisture content and temperature of the material [21]. The allicin content of the garlic drying during was determined using the modified Lawson's method [22]. Sharma [23] studied the colour change of fresh garlic in a hot air dryer at $700 \mathrm{C}$ and rather large number of mercaptans, disulfides, trisulfides and thiophenes [24]. Li Y [25] however, reported 90.2 percent retention of thiosulphates with microwave-vacuum and freeze drying. More than $50 \%$ of the water is taken out with the help of hypertonic solutions. After that, the fruit pieces are very soft and are still subjected to spoilage by a variety of microorganisms. The water content needs to be lowered further to gain microbiological stability without cool storage. Osmotic dehydration (OD) and pretreatment prior to drying was found advantageous for improving the product quality and for decreasing energy consumption [26,27].

Today's consumer expectation for better quality, safety and nutritional value drives research and improvement of drying technologies. The heat and mass transfer coefficients are important parameters in the simulation of drying rates, since the temperature difference between the air and food product varies with these coefficients. Jain D [28] evaluated the convective heat-transfer coefficient for some of the crops (green peas, green chillies, white gram, onion, onions and potatoes) under solar drying condition and developed a mathematical model to predict the drying parameters [29]. Further studies the dependence of convective heat-transfer coefficient on the drying time during complete solar drying process of green peas and cauliflower. The present work was focused on estimating the convective heat and mass transfer coefficients and to study the moisture transport during microwave-convective drying of garlic cloves.

The study was mainly concerned with the development of a mathematical model of a thin layer drying for garlic using an indirect forced convection solar dryer under conditions typical of Minufiya, Egypt. Studies of some pretreatments affecting the changes in the various chemical and physical constituents of garlic during the drying process were considered. Quality attributes of dried product were evaluated. One of the most important ways to reduce the adverse influence of drying on food quality or to ensure basis quality properties on food quality or to ensure basis quality properties of the final product is to carefully design the process and implement it consistently [30]. The moisture removal during drying processes is greatly affected by the drying air conditions as well as the characteristic dimension of material, whereas all other process factors have a practically negligible influence [31]. Several quality standards for dried garlics were developed over time; the official standards of the American Dehydrated Onion and Garlic Association (ADOGA) are considered the primary standard.

\section{Methods of Drying}

\section{Hot air drying}

Hot-air drying of garlic slices in a common fixed bed method is unfortunately not suitable due to a significant decrease in the quality of dried product related to the fresh one. Applying high temperature (about $60^{\circ} \mathrm{C}$ ) in a fixed bed drying causes an increase in drying period, energy consumption, color degradation and mass transfer. Hot-air drying samples were dried at 50 0C using a hot-air drying oven (DMC-122SP, Daeil Engr. Co., Korea) for $48 \mathrm{~h}$ to a final moisture content of approximately 5-7\%, Moisture-Free Basis (MFB), which was determined by the gravimetric method at $105^{\circ} \mathrm{C}$, till the weight reached a constant value. A major disadvantage associated with hot air drying is that it takes long time even at high temperature, which results in degradation of the dried product quality. Compared with hot air drying, combined microwave-hot air could reduce the drying time of biological materials without damaging the quality attributes of the finished products [32]. The food materials reportedly have been dried using microwave-convective technique include corn [33-35] apples and mushrooms [36], and various medicinal plants [32]. However, no work has been reported on the drying of garlic. The evolution of a microwave-hot air drying process to produce high-quality dried garlic in a relatively short time could make a significant contribution to the garlic processing industry. Therefore, the main objective of was to explore the possibility of using combined microwave-convective drying technique for processing of garlic and assessment of the quality of finished product. Many studies have recently provided strong evidence that most of these biological functions of garlic are attributed to allicin [37,38]; Tulasidas TN [39] reported that no compound outside the thiosulphate, of which allicin is about $60-80 \%$ has been found that accounts for a significant portion of the pharmaceutical activities of crushed garlic at levels representing normal human consumption (2-5 g/d).

\section{Solar and Open sun drying}

Recent efforts to improve on sun drying have led to solar drying. Solar drying also uses the sun as the heat source. A foil surface inside the dehydrator helps to increase the temperature. Ventilation speeds up the drying time. Shorter drying times reduce the risks of food spoilage or mold growth. It is a complex operation involving heat and mass transfer which may cause changes in product quality. Physical changes that may occur include shrinkage, puffing and crystallisation. In some cases, desirable or undesirable chemical or biochemical reactions may occur leading to changes in colour, texture, odour or other properties of the food product. Drying can either be an alternative to canning and freezing or complement these methods. Drying occurs by vaporisation of the liquid by supplying heat to the wet feedstock. Heat may be supplied by conduction (contact or indirect dryers), by convection (direct dryers), by radiation or volumetrically by placing the wet material in a microwave or radio frequency electromagnetic field. Over $85 \%$ of industrial dryers are of 
convective type with hot air or direct combustion gases as the drying medium.

Solar drying is often differentiated from "sun drying" by the use of equipment to collect the sun's radiation in order to harness the radiative energy for drying applications. Sun drying is a common farming and agricultural process in many countries, particularly where the outdoor temperature reaches $30^{\circ} \mathrm{C}$ or higher. In many parts of South East Asia, spice $s$ and herbs are routinely dried. However, weather conditions often preclude the use of sun drying because of spoilage due to rehydration during unexpected rainy days. Furthermore, any direct exposure to the sun during high temperature days might cause case hardening, where a hard shell develops on the outside of the agricultural products, trapping moisture inside. Therefore, the employment of solar dryer taps on the freely available sun energy while ensuring good product quality via judicious control of the radiative heat. Solar energy has been used throughout the world to dry products. Such is the diversity of solar dryers that commonly solar-dried products include grains, fruits, meat, vegetables and fish. A typical solar dryer improves upon the traditional open-air sun system in five important ways [40].

\section{Infra-Red drying}

Microwave and infrared (IR) drying have been studied for achieving fast drying and reducing quality loss of fruits and vegetables [41]. A combination of hot air and microwave drying of osmotic dehydrated blueberries had similar or better product quality compared with freeze-dried products with much reduced drying time [42]. Compared with hot air drying, IR heating offers many advantages such as greater energy efficiency, heat transfer rate, and heat flux, which results in reduced drying time and higher drying rate. It has been investigated as a potential method for increasing heating efficiency and obtaining high quality of dried foodstuffs, including peaches [43], carrots [44], onions [45], rice [46], and many other fruits and vegetables [47].

\section{Fluidized bed drying}

Thin layer drying properties of high moisture garlic sheets under semi fluidized and fluidized bed conditions with high initial moisture content (about $154.26 \%$ d.b.) were studied. Air temperatures of 50, 60, 70 and $80^{\circ} \mathrm{C}$ were applied to garlic samples. Among the applied models, Page model was the best to predict the thin layer drying behavior of garlic sheets.

\section{Dried garlic Products}

Garlic Powder: In India due to lack of suitable storage, transport and processing facilities, heavy losses are incurred both in terms of quality and quantity due to respiration, transpiration and microbiological spoilage. Through garlic is produced abundantly and consumed as such, little efforts have so far been made to produce dehydrated garlic and garlic powder.

Garlic Paste: Kimizuka A [48] described a method for marking garlic paste with the same flavour as fresh garlic. The cleaned bulbs are broken into cloves, peeled and boiled carefully to obtain a homogeneous paste. To ensure a pleasing appearance and good shelf life an addition of $0.1 \% \mathrm{SO}_{2}, 15 \% \mathrm{NaCl}$ and $0.05 \%$ ascorbic acid is recommended. Brondnitz MH [49] prepared garlic paste with a TSS and $\mathrm{pH}$ value of $33 \%$ and 4.1 respectively, from fresh garlic by addition of $10 \% \mathrm{NaCl}(\mathrm{w} / \mathrm{w})$ and citric acid. Appearance of green pigment was noticed in the product during preparation. Paste was thermally processed at 70.80 or $90^{\circ} \mathrm{C}$ respectively for 15 minutes. Greening of paste decreased with increase in temperature. The product was found to be shelf stable at $25^{\circ} \mathrm{C}$ for a period of at least 6 months.

Garlic Extract: Several patents have been registered to prepare garlic juice or extract. Patented the method of obtaining 2-component extract of garlic. According to the process the garlic is cooled and ground for aqueous extraction to yield enzyme extract called the first component. The residue is then extracted with liquid $\mathrm{CO}_{2}$ to give enzyme-free extract called second component. The two components are mixed together prior to being added to food products. 8 patented a method in which garlic was mixed with a dehydrating agent, viz. dried spices or dry waste material from extraction of spices, in a spice to garlic ratio of 1:1, and the mixture was then ground and extracted with liquid $\mathrm{CO}_{2}$. This method claimed to increase the yield, enriched with biologically active substances. Funebo T [50] patented a method for producing deodorized liquid garlic extract. The method involves merely mixing any edible oil into the garlic juice squeezed from the garlic bulbs, and holding the juice for a predetermined period in a vessel under a specific condition until has liquid garlic extract was completely precipitated. The resultant garlic extract had no unpleasant odour and acrid taste. Chopping garlic and aging it in alcohol for almost two years made aged odourless garlic extract. The extract contained thioallyl compounds.

Kim MR [51] patented a flavour enhancing seasoning containing deodorized garli extract and process. Blanching garlic, and extracting the blanched product with water prepared the seasoning. The extract produced was deodorized and concentrated, to provide seasoning additives that dramatically improved flavour fullness, depth and duration. The extract could be advantageously combined with flavour intensifiers such as monosodium glutamate.

Garlic Oil: Garlic oil is derived by steaming crushed garlic and capturing the resultant oil released. The yield of garlic oil is around 0.46-057 \% on moisture free basis, and it makes it quite expensive. The specific gravity and refractive index of garlic oil at $25^{\circ} \mathrm{C}$ is $1.091-1.098$ and 1.5740-1.5820 respectively. Several workers have studied the odorous constituents of garlic oil [41]. The compounds reported ate listed in Table 2.

The major component of distilled oil of garlic is diallyl disulphide. Vegetable oil is usually added to the garlic oil to make capsules of garlic oil. It has a strong smell of garlic and is also used as a foodflavouring agent. Hibi T [52] patented the method of processing garlic and preparing ajoene-containing edible oil products. 100 parts (by wt.) water and 100 parts garlic bulbs are mashed together. The mashed mixture, or juice extracted from the mixture, is brought into contact with edible oil and the $\mathrm{pH}$ of this mixture is adjusted to neutral or between $\mathrm{pH} 6$ and [53]. The resulting mixture is incubated between 0 and $50^{\circ} \mathrm{C}$ in order to from $\mathrm{Z}$-ajoene in the oil.

Macerate of Garlic: It is a product formed when garlic is chopped or macerated with salad oils or other edible oils. Macerate of garlic is a rich source of naturally formed garlic derived compounds having the scientific names ajoene, methyl ajoene, and dithiins. These products are stable enough to be stored at room temperature for more than a year. 
Page 5 of 6

\begin{tabular}{|l|l|l|}
\hline Dimethyl sulphide & Diallyl disulphide & Diallyl trisulphide \\
\hline Diallyl sulphide & Allyl propyl disulphide & Methyl allyl trisulphide \\
\hline Methyl allylsulphide & Methyl allyl disulphide & Met hyl propyl trisulphide \\
\hline Dimethyl disulphide & Methyl propyl disulphide & Diallyl thiosulphinate \\
\hline Dipropyl disulphide & Dimethyl trisulphide & Methanol \\
\hline Sulphur dioxide & 2-Propen-1-ol & p-Cymene \\
\hline
\end{tabular}

Table 2: Volatile compounds obtained from garlic Source: [44].

Pickled Garlic: Whole, sliced, cubed garlic is pickled in vinegar or brine or vegetable oil or their combinations. Picking garlic in vinegar leads to formation of S-allyl cysteine. Funebo studied chemical characteristics and storage stability of garlic pickled in brine $(5 \%$ $\mathrm{NaCl}$ ) acidified with a lactic acid-acetic acid mirture. The concentration of each acid $(0.74 \%, w / v)$ in the brine gave a $\mathrm{pH}$ of 4.0 after equilibrium between garlic cloves and brine. Blanching (conventional or by microwave) prior to packaging was very important for the preparation of high-quality pickled garlic. It resulted in elimination of the pungent flavour by deactivation of the enzyme allinase, elimination of green coloration or formation of gas, and reduction of firmness.

Dehydrated Garlic: The removal of water from garlic results in a substantial reduction in bulk, enabling savings in storage space and reducing the weight to be transported. Garlic is dried to mainly produce slices, cubes chunks and powder. Powered garlic attempts to mirror the chemical profile of fresh garlic in a stabilised from. Garlic is peeled, sliced, sliced and dried before pulverising. In this process a little allicin is formed where thus cloves are sliced, but most of the cells are unbroken when dried and the alliin and allinase remain separate. Dried garlic has many uses in restaurants, hotels, and in other eating establishments and in the home. Also it is used in the flavouring of tomato products, canned soups, meat products such as sausage, hamburger, and salami, as well as in certain salad dressings. As a medicine it is used to form tablets. Studies on the stability of allicin, allyl sulphides and antibacterial activity, retention of colour and flavour, satisfactory re-hydration characteristics and drying rates during dehydration has been extensively studied. Screening of varieties from the viewpoint of dehydration has also been done.

\section{Conclusion}

The purpose of the present study was to test and to evaluate the effect of different levels of infrared radiation intensity and air velocity on drying characteristics and quality changes of thin layer garlic slices under convection and combined heating modes. The major quality problems faced during garlic drying loss of flavour, discoloration and poor rehydration characteristics of the dried garlics. Drying is an industrial preservation method in which water content and water activity of the fruits and vegetables are decreased by heated air to minimized biological, chemical and microbial deterioration. Drying is a process of simultaneous heat and mass transfer. Mathematical modelling help to of drying process help in understanding the physics of drying. At this moisture level, the chances of insects and molds infestation are minimized and thus the commonly can keep well in storage. To obtain the dehydrated product of high quality, the drying process should be such that it allows effective retention of colour appearance, flavour, taste and nutritive value, comparable to fresh vegetables. The technique of drying is probably the oldest method of food preservation practiced by mankind for the extension of food shelf life. The use of artificial drying to preserve agricultural commodities is expanding, creating a need for more rapid drying techniques and methods that reduce the large amount of energy required in drying processes. In case of garlic is a antioxidant product used for several medicinal purposes. New and innovation techniques that increase drying rates and enhance dried garlic quality are receiving considerable attention.

\section{References}

1. Prakash S, Dekshinamarthy A, Shukla BD (1994) Status of garlic storage and processing in India. Spice India 7: 20-24.

2. Anonymous, (1993) Anonymous (1997) Project Opportunities for Food Industries, Ministry of Food Processing Industries, GIO and CFTRI, Mysore, India.

3. APEDA Export Statement (2002) FAO UN Food \& Agriculture Organisation (FAO).

4. Eke AB, Onyenekwum PC, Asota CN, Kalu RN (1995) Effect of solar and traditional open sun on the microbial loads and some nutrients of tomato paper present at the 17th annual conference of Nigerian society of Agricultural Engineers, Federal University of Technology, Nigeria.

5. Dash SK, Bhatnagar S (1994) Multistage dehydration process of garlic. Indian Journal of Agricultural Engineering 1: 33-36.

6. Dawn CP, Shreenarayanan VV (1998) Studies on dehydration of garlic. Journal of Food Science and Technology 35: 242-244.

7. Mazza G, Le Maguer M (1980) Dehydration of onion: Some theoretical and practical considerations. J Food Technology 15: 181-194.

8. Singh U, Jain SK, Doshi A, Jain KH, Chahar KV (2008) Effects of pretreatments on Drying Characteristics of Bulton Mushroom. Int J Food Engg. The Berketey Electronic Press.

9. Banga JR, Singh RP (1994) Optimization of air drying of foods. J Food Engg 23: 189-211.

10. Prakash S, Jha SK, Datta N (2004) Performance evolution of balanced carrots dried by three different driers. Journal of Food Engineering 62: 305-313.

11. Brewester JL (1997) Onions and Garlic. The physiology of vegetable crops. CAB International, Cambridge, UK.

12. Sharma GP, Prasad S (2006) Optimization of process parameters for microwave drying of garlic cloves. Journal of Food Engineering 75 : 441-446.

13. Afzal TM, Abe T (2000) Simulation of moisture changes in barley during far infrared radiation drying. Computers and Electronics in Agriculture 26: 137-145.

14. Anwar SI, Tiwari GN (2001) Evaluation of convective heat transfer coefficient in crop drying under open sun drying conditions. Energy conversion and management 42: 627-637. 
Page 6 of 6

15. APEDA (2002) Export Statement.

16. Sharma A, Chen CR, Vu Lan N (2009) Solar-Energy drying systems; A review. Renewable and Suntinable Reviews 13: 1185-1210.

17. Fellows PI (1998) Food Processing Technology. Ellis Horwood Chichester. pp: 281-294.

18. Mongpraneet S, Abe T, Tsurusaki T (2002) Accelerated drying of Welsh onion by far infrared radiation under vacuum conditions. J Food Engg 55: $147-156$.

19. Keey RB (1980) Theoretical foundations of drying technology. In Advances in Drying, 1, ed. A.S. Mujumdar. Hemisphere Publishing, NY.

20. Opera UK, Geyer M (1999) Onion storage. CIGR Handbook of Agricultural Engineering Volume IV Agro Processing. The American Society of Agricultural Engineers.

21. Sica Sol (1969) Method for marking garlic paste. French Patent 1560735.

22. Togrul H (2006) Suitable drying model for infrared drying of carrot. Journal of Food Engineering 77: 610-619.

23. Sharma GP, Prasad S (2001) Drying of garlic (Allium sativum) cloves by microwave-hot air combination. Journal of Food Science 46: 410-413.

24. Lindsay RC (1996) Food Additives. In India Chemistry by Owen R. Fennema. Third edition. Marcel Dekker, Inc. New York, USA.

25. Li Y, Xu Shi-ving (2007) Preparation of Garlic Powder with high allicin content. Agricultural Sciences China 6: 890-898.

26. Mandala LG, Anagnostaras EF, Oikonomou CK (2005) Influence of osmotic dehydration conditions on apple air-drying kinetics and quality characteristics. Food Engineering 69: 307-316.

27. Lawson ID, Han G, Han P (1995) Spectrophotometric method for quantitative determination of allicin and total garlic thiosulfinates. Analytical Biochemistry 225: 157-160.

28. Jain D, Tiwari GN (2003) Thermal aspect of open sun drying of various crops. Energy 28: 37-54.

29. Jain D, Tiwari GN (2004) Effect of greenhouse on crop drying under natural and forced convection-I: Evaporation of convective moisture diffusivity from drying data. J Food Sci 55: 218-231.

30. Liwicki PP (2006) Design of hot air drying for better foods. Trends in Food Science and Technology 17: 153-163.

31. Kiranoudis CT, Maroulis ZB, Tsami E, Marinos-Kpuris D (1997) Drying kinetics of some fruits. Drying Technology 15: 1399-1418.

32. Ren G, Chen F (1998) Drying of American ginseng (Panax guinseng) roots by microwave hot air combination. Journal of Food Engineering 35: 433-445.

33. Duarte CR, Vieira Neto JI, Lisboa, MH, Murate VV, Barroza MAS (2004) Experimental study and simulation of mass distribution of covering layer of soybean seeds coated in a spouted bed. Erazilian Journal of Chemical Engineering 21: 59-67.

34. Moreno J, Bugue-no G, Velasco V, Petzold V, Tabilo-Munizaga G (2004) Osmotic dehydration and vacuum mpregnation on physicochemical properties of Chilean papaya. Food Science 69: 102-106.
35. Prabhanjan, Ramaaswamy, Raghavan GSV(1995) Microwave-assisted convective air drying of thin layer of carrots. Journal of Food Engineering 25: 283-293.

36. Gunasekaram S (1990) Drying corn using continuous and pulsed microwave energy. Drying Technology 8: 1039-1047.

37. Krest I, Glodek J, Keusgen M (2000) Cystenine sulfoxides and allinase activity of some Alliumn spices. Journal of Agricultural and Food Chemistry 48: 3753-3760.

38. Baysal T, Icier F, Ersus S, Yldz H (2004) Effects of microwave and infrared drying on the quality of carrot and garlic. European Food Research and Technology 218: 68-73.

39. Tulasidas TN, Ramaaswamy, Norris ER (1993) Microwave and convection drying of grapes. Transaction of ASAE 36: 1861-1865.

40. Wang J (2002) A single-layer model for far-infrared radiation drying of onion slices. Drying Technology 20: 1941-1953.

41. Sokhansanj S, Jayas DS (1987) Drying of foodstuffs. In: Handbook of International Drying, et. A.S. Mujumdar, Marcel Dekker Inc; NY.

42. Volonchuck SK, Shornikova LP (1998) Full-value nutrition and infrared drying of raw vegetables. Pishchevaya Promyshlennost 5: 16-17.

43. Afzal TM, Abe T(1997) Combined convection and far infrared radiation drying of rough rice. ASAE Annual International Meeting, 10e14 August, Minneapolis, MN, USA.

44. Venkatachalapathy K, Raghavan GSV (1998) Microwave drying of osmotically dehydrated blueberries. Journal of Microwave Power and Electromagnetic Energy 33: 95-102.

45. Wang J, Sheng K (2006) Far-infrared and microwave drying of peach. Food Science and Technology 39: 247-255.

46. Ahmed J, Pawanpreet, Shivhare US (2001) Physico-chemical and storage characteristics of garlic paste. J Food Pro Preser 25: 15-23.

47. Morinaga M (1983) Method for producing deodorized liquid garlic extract.

48. Kimizuka A, Ueda Y, Sakaguchi M, Miyajjma R (1988) Flavour enhancing seasoning containing deodorized garlic extract and process.

49. Brondnitz MH, Pascale JU, Van Derslice L (1971) Flavor components of garlic extract. J Agric Food Chem 19: 273-245.

50. Funebo T, Ohlsson T (1998) Microwave assisted air dehydration of apples and mushroom. Journal of Food Engineering 38: 353-368.

51. Hibi T (1997) Method of processing garlic and preparing ajoenecontaining edible oil products. United State Patent.

52. Kim MR, Yan JH, Soc DE (1994) Correlation between pungency and allicin content of pickled garlic during aging. J Korean Soc Food Nutr 23: 805-810.

53. Avagimov VB, Bessarabow VI, Kas'yanor GI, Pekhor AV, Stefsnskaya NV (1982) Method of obtairing garlic extract. USSR Patent, SU. 